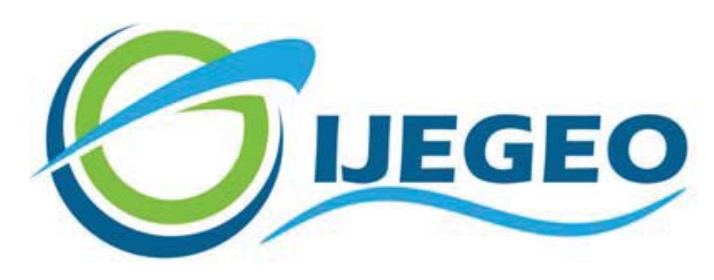

International Journal of Environment and Geoinformatics (IJEGEO) is an international, multidisciplinary, peer reviewed, open access journal.

\title{
Turkey's interest in the Arctic region: the evaluation of being a party to the Svalbard Treaty
}

\section{Oktay ÇETİN, Y. Barbaros BÜYÜKSAĞNAK}

\author{
Chief in Editor \\ Prof. Dr. Cem Gazioğlu \\ Co-Editors \\ Prof. Dr. Dursun Zafer Şeker, Prof. Dr. Şinasi Kaya, \\ Prof. Dr. Ayşegül Tanık and Assist. Prof. Dr. Volkan Demir
}

Editorial Committee (September 2021)

Assoc. Prof. Dr. Abdullah Aksu (TR), Assit. Prof. Dr. Uğur Algancı (TR), Prof. Dr. Bedri Alpar (TR), Assoc. Prof. Dr. Aslı Aslan (US), Prof. Dr. Levent Bat (TR), Prof. Dr. Paul Bates (UK), İrşad Bayırhan (TR), Prof. Dr. Bülent Bayram (TR), Prof. Dr. Luis M. Botana (ES), Prof. Dr. Nuray Çağlar (TR), Prof. Dr. Sukanta Dash (IN), Dr. Soofia T. Elias (UK), Prof. Dr. A. Evren Erginal (TR), Assoc. Prof. Dr. Cüneyt Erenoğlu (TR), Dr. Dieter Fritsch (DE), Prof. Dr. Çiğdem Göksel (TR), Prof.Dr. Lena Halounova (CZ), Prof. Dr. Manik Kalubarme (IN), Dr. Hakan Kaya (TR), Assist. Prof. Dr. Serkan Kükrer (TR), Assoc. Prof. Dr. Maged Marghany (MY), Prof. Dr. Michael Meadows (ZA), Prof. Dr. Nebiye Musaoğlu (TR), Prof. Dr. Masafumi Nakagawa (JP), Prof. Dr. Hasan Özdemir (TR), Prof. Dr. Chryssy Potsiou (GR), Prof. Dr. Erol Sarı (TR), Prof. Dr. Maria Paradiso (IT), Prof. Dr. Petros Patias (GR), Prof. Dr. Elif Sertel (TR), Prof. Dr. Nüket Sivri (TR), Prof. Dr. Füsun Balık Şanlı (TR), Prof. Dr. Uğur Şanlı (TR), Duygu Ülker (TR), Prof. Dr. Seyfettin Taş (TR), Assoc. Prof. Dr. Ömer Suat Taşkın (TR), Assist. Prof. Dr. Tuba Ünsal (TR), Dr. Manousos Valyrakis (UK), Dr. İnese Varna (LV), Dr. Petra Visser (NL), Prof. Dr. Selma Ünlü (TR), Assoc. Prof. Dr. Oral Yağcı (TR), Prof. Dr. Murat Yakar (TR), Assoc. Prof. Dr. İ. Noyan Yılmaz (AU); Assit. Prof. Dr. Sibel Zeki (TR)

Abstracting and Indexing: TR DIZIN, DOAJ, Index Copernicus, OAJI, Scientific Indexing Services, International Scientific Indexing, Journal Factor, Google Scholar, Ulrich's Periodicals Directory, WorldCat, DRJI, ResearchBib, SOBIAD 


\title{
Turkey's interest in the Arctic region: the evaluation of being a party to the Svalbard Treaty
}

\author{
Oktay Çetin $^{1 *}$ (D) Y. Barbaros Büyüksağnak ${ }^{2}$ iD
}

${ }^{1}$ Pîrî Reis University, Department, Maritime Faculty, Maritime Transportation and Engineering, İstanbul, Turkey

${ }^{2}$ Pîrî Reis University, Maritime Higher Vocational School, Management and Organization Department, İstanbul, Turkey

* Corresponding author: O. Çetin

Received: 26.02.2020

E-mail: ocetin@pirireis.edu.tr Accepted: 15.03 .2021

How to cite: Çetin and Büyüksağnak (2021). Turkey's interest in the Arctic region: the evaluation of being a party to the Svalbard Treaty. International Journal of Environment and Geoinformatics (IJEGEO), 8(3):350-358. doi. 10.30897/ijegeo.887540

\begin{abstract}
The Arctic Ocean's becoming open wider to international navigation for most of the time in parallel with global warming has attracted the attention of the world to this region. As today's economic conditions reveal the necessity to deliver products to the global market as quickly as possible, the possibility of intense use of the Arctic Ocean is increasing. This study aims to emphasize the increasing importance of the Arctic region from a maritime economics perspective and on the other hand to evaluate the possible results of being a party for Turkey to the Svalbard (originally Spitsbergen) Treaty. It is expected that the increase in global temperatures will result in important outcomes in the region especially regarding the new emerging navigational routes and sharing of the natural resources in the region. Analysis has been made on the impact of new security concerns on the sustainable maritime economy likely to arise in the Arctic region. As a result, the importance of mutual international efforts to maintain stability was emphasized and the importance of being a party to the Svalbard Treaty for Turkey was highlighted.
\end{abstract}

Keywords: Arctic, Svalbard Treaty, Maritime Strategy, Geostrategy, Maritime Economics.

\section{Introduction}

Svalbard, one of the high-Arctic archipelagos with a total landmass of $61,000 \mathrm{~km}^{2}$ and has the northernmost permanent settlements, is a part of the Kingdom of Norway whose sovereignty is confirmed by a treaty of 1920 signed in Paris. As the human-induced climate change and melting and decreasing sea ice have caused physical and socio-economical transformations within the Arctic region, Svalbard got more of its share.

The Arctic has warmed up more than twice as fast as the rest of the Earth, a phenomenon accepted as Arctic amplification (Serreze and Barry, 2011). Because of the warming of the atmosphere, the sea ice extent diminishes in summer at about $12 \%$ per decade, and the ocean can reflect only $10 \%$ of the sun's rays which is known as "the albedo effect". As a consequence, when the ocean warms up, the melting of the sea ice cover increases (German Arctic Office, 2020a; Moholdt et al., 2010).

This unprecedented change in the Arctic has various and deep effects on people living in the Arctic, ecosystems, resources as well as the geopolitics of the region. The changes do not affect only the Arctic but also the rest of the globe, not only through the loss of glaciers' contribution to sea-level rise but also through the role in the global climate system and on mid-latitude weather patterns and also with its influence on a great ocean conveyor belt which is also known as "thermohaline circulation". It is estimated that the Arctic Ocean could be mostly free of sea ice in summer periods as early as the late 2030s (ACIA, 2004; AMAP, 2017; AMAP, 2019).

As the Arctic has swiftly been transforming into a new state, Svalbard also experiences the outcomes of climate change at a more surpassing rate compared to any other place in Norway (Kaltenborn, Østreng and Hovelsrud, 2019). Owing to its unique location between the geographic North Pole and the northern coasts of Scandinavia, Svalbard has been an important region of intensive scientific researches and observations, yet it has the highest warming rate within the Arctic region (The RCN, 2019). That is why many states tend to increase their interest in the Arctic, especially in the last 40 years. It was stated that the rate of melting of sea ice, which reaches $20 \%$ in the last years in the Arctic, may increase gradually until 2040, and when approaching 2040, sea ice may melt completely during the summer months. Around 2050, the soils of Northern European countries will probably be flooded due to the high water level (Aksenov et al., 2017; Ülker et al., 2018; Cheng et al., 2019; Selin et al., 2020; Schuler et al., 2020; Erol et al., 2021). If global warming continues at this level, it is expected that the importance of new maritime trade routes in the Arctic region, which can be used very limitedly today, will increase gradually.

The Arctic region surrounding the North Pole comprises the Arctic Ocean surrounded by the northern parts of three continents; Asia, Europe, and North America (Figure 1). The Arctic Ocean is unlike the other oceans on earth and due to its special location and climate, the 
lands which surround it are one-of-a-kind (NSIDC, 2021a). It is covered with ice and considered the smallest ocean in the world with an area of 14,090,000 $\mathrm{km}^{2}$ and five times larger than that of the largest sea, the Mediterranean. It is shallow compared to other oceans and its average depth is 987 meters (Britannica, 2021). These descriptions of the Arctic have also become more attentive regarding the human and political factors that have legislative authority in the region for global politics (AMAP, 1998; Greaves, 2016; Pezard et al., 2018; Togt, 2019).

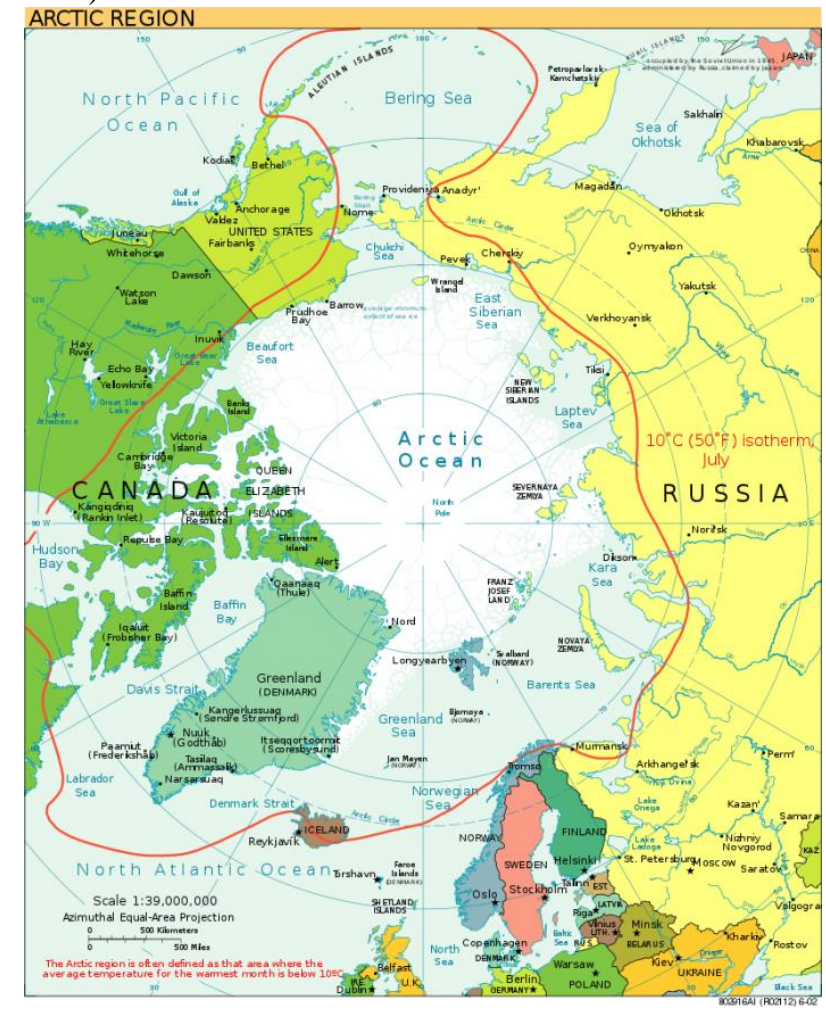

Figure 1. The Arctic Region with Different Definitions (NSIDC, 2021)

Currently, the Arctic is considered to compose of territories and sub nautical areas within eight sovereign states that listed as Canada, Denmark, Finland, Iceland, Norway, Russia, Sweden, and the USA, while is considered to accommodate nearly four million inhabitants with $50 \%$ being Russian (Huebert et al., 2012). The Arctic terrestrial landscape covers an area of approximately 13.4 million $\mathrm{km}^{2}$ (AMAP, 1998).

\section{Materials and Methods}

The aim of this study is (1) To emphasize the increasing importance of the Arctic region from a maritime economics perspective and (2) To discuss Turkey's interest in the Arctic region and evaluate being a party to the Svalbard Treaty.

Within the scope of this study, the document analysis method, as one of the qualitative research methods, was used. First of all, all books, articles, and official documents published in Turkish and English regarding the Svalbard Islands, the Svalbard Treaty, and the recent developments in the Arctic region were reviewed and included in the scan. The sources included in the survey were analyzed using the document analysis method and the findings were discussed in the conclusion section.

There were discussions about the importance of joining the Svalbard Treaty for Turkey in the media. A common understanding and consensus at the earlier stages of the discussions in the newspapers had been reached in 2020 . It has been discerned that there are only a few publications about Svalbard Treaty in Turkish and it is decided to write an article on this subject.

\section{Literature Review \\ The Arctic region with its security and geopolitical dimension}

The results of the Cold War have changed the geopolitical situation that had kept the Arctic away from superpower competition, smothering occasions for the development of the region, and the requirement for a considerable amount of military deployment to this sea area. This resulted in the interaction of political conversion with the altering environment which influenced the security of the Arctic countries in a minimum of three ways: catalyzation of regional cooperation; increase in risks of exceptional border disputes and resource development. These changes caused the Arctic to become a more attainable area to countries and commercial persons and contribute to the rise of a variety of non-traditional security problems (Greaves, 2016; Pezard et al., 2018; Togt, 2019).

From the conventional interstate security point of view, the Arctic region was much secure between 1991 through 2010 relative to the security in the previous years. In the modern era, however, the Arctic has experienced remilitarization and improvements in international issues relatively. Arctic nations have extended their military expenses and actions, while certain nations even have used discourses in revealing their regional interests. Circumpolar nations have made reoccurring investments in Arctic military capabilities, reacted and overreacted to military actions of each other, and expulsed claims of nations having no coast to the Arctic Ocean such as South Korea and China to become a more valid factor in the region, even though these countries have made investments in Arctic researches and ice-breakers (Huebert et al., 2012). The maritime sector, due to growth in common activities such as tourism and destination-based shipping, also needs assets to be placed within regions to provide means of search and rescue for potential accidents.

To increase regional coordination and cooperation, a ministerial-level forum called the Arctic Council has been created among the Arctic States in 1996. Indigenous peoples living in the region have also participated in this forum. Eight Arctic states joined the Council, whose main aim is to protect the environment (Ho, 2009; Lasserre, 2014).

In addition to protecting the environment, the Arctic Council also aims to find solutions to the problems that the countries in the Arctic have with each other in this region. Among these problems, the management of the 
region and its use in maritime activities stand out. Although the melting of the sea ice in the Arctic Ocean caused environmental problems, it also created new commercial opportunities for the countries in the region and economically strong states. New commercial routes have emerged with the melting of ice in some parts of the Arctic Ocean, which have been covered with sea ice almost most of the year for centuries (Figure 2). The desire of the countries in the region to dominate new shipping routes due to their commercial interests is frequently the agenda item of the Arctic Council (Lasserre, 2014).

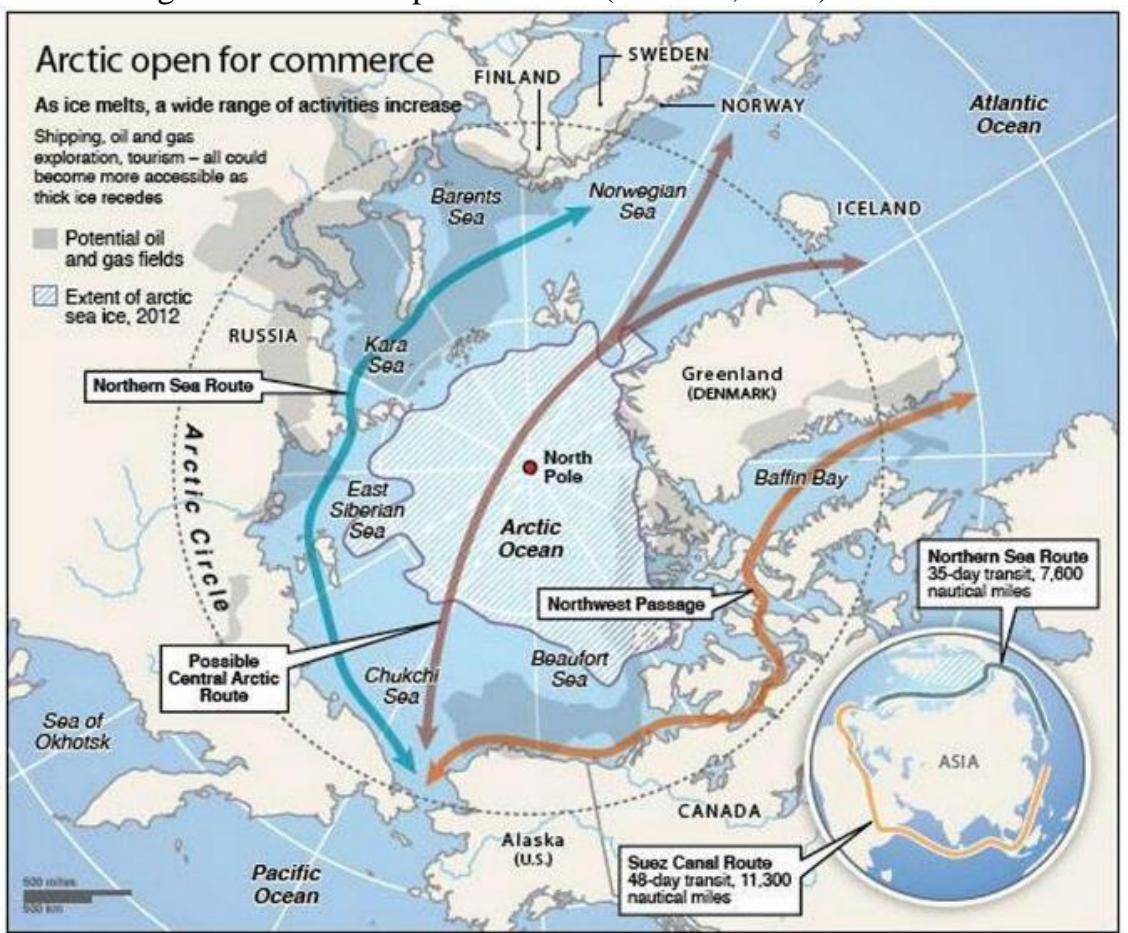

Figure 2. Arctic Shipping Routes, (Eurasian Geopolitics, 2021)

With the increasingly diminishing of the sea ice, states have turned their interest more and more to the delimitation of their maritime boundaries in the Arctic region which resulted in them expressing their interests in many disputes. This situation has proceeded with them coinciding with their requirements to declare their claims for their continental shelves in the ratification of the UN Convention on the Law of the Sea (UNCLOS) (Riddell-Dixon, 2008). While in the Barents Sea in 2010, Norway and Russia have carried out negotiations about their boundaries, maritime disputes still exist among Canada and Greenland (Denmark) and Canada and the United States. There also are submissions among the Canadian, Danish, and Russian continental shelves under UNCLOS to the UN Commission on the Limits of the Continental Shelf (CLCS) which has geographic overlaps.

Additionally, to symbolic value to particular Arctic geographic regions, mostly to the North Pole, the real reason behind countries' interests in trying to improve and prove their Arctic sovereignty, is the wish for possibly the greatest financial benefit in the future from resources in the Arctic region (Mazo, 2014). In the future, the focus of attention may be on shipping routes, fishing, unexplored oil and natural gas resources known to exist in the region, and hydrocarbons under risk (Gautier et al., 2009).

Change in the environment has caused the occurrence of unconventional security issues. Although unconventional risks have not yet been realized in the region, more conventional risks such as acts of terrorism, drug and arms smuggling, human trafficking have caused a high level of attention to shift to the Arctic region and have led armed forces to create training scenarios (Chater and Greaves, 2014). Many of these unconventional security issues are also about the exploitation of Arctic resources. Newly established security governance applications are currently being applied as a response to perils concerning the increasing capacity of maritime traffic, for instance, new conventions on region-based search and rescue operations and oil spill emergency response operations (Fondahl and Sirina, 2006).

Considering the interchanging environment causing new perils, such as growing risks to ships, to oil rigs caused by sea ice, unforeseeable weather conditions, and newly occurring security issues, including the Arctic ecosystem itself. Many circumpolar states have also created a tendency for activism or remonstrations concerning global warming and resource exploitation as an unlawful act as well as criminal, terrorist activities or threats to their national interests. It is stated that Canada and Russia, specifically, have been establishing new legislative movements to police domestic resistance and allow them to legalize their goal for resource extraction (United Nations, 2009). Thus, security issues in the Arctic have been formed as direct impacts of environmental changes and enabled activities in course of the environment interceding concepts of security perils in the Arctic region. Currently, the security issues pinpointed by Arctic states emphasize the relationships 
among changes in the environment, national defense, sovereign territoriality, resource exploitation, and local political opposition (Greaves, 2016; Pezard et al., 2018; Togt, 2019).

Arctic local inhabitants have generally defined environmental changes as a threat to their security, although such declarations have not been acknowledged by the sovereign nations. People who are affected heavily by the consequences of Arctic climate change can mobilize at least a sufficient political response because they cannot successfully perform security demands on issues facing their communities (Greaves, 2016; NSIDC, 2021b).

\section{The importance of the Svalbard Islands in the Arctic}

Its unique geography and easy accessibility for tourists, researchers, and students, research programs, and higher education opportunities in different Arctic disciplines, research stations, and well-organized infrastructures connected to international networks made Svalbard Islands become one of the most important Arctic scientific research areas and tourist destinations (Figure 3). Additionally, in the Global Seed Vault in Longyearbyen, deep inside a mountain and well above sea level, seeds vital to humanity's future are being stored. A very large amount of these seeds from almost one million varieties of food plants are kept in a huge safety depot that houses the world's largest agricultural biodiversity collection. The Global Seed Vault, also called the "doomsday vault", was created for use of humankind in the event of an apocalyptic event or a global disaster (Duggan, 2021). In the year 2020, additional 82,501 seed samples have been safeguarded in the Vault, thus reached 1,074,533 samples in total originating from almost every country in the world, including Turkey (Svalbard Global Seed Vault, 2021).

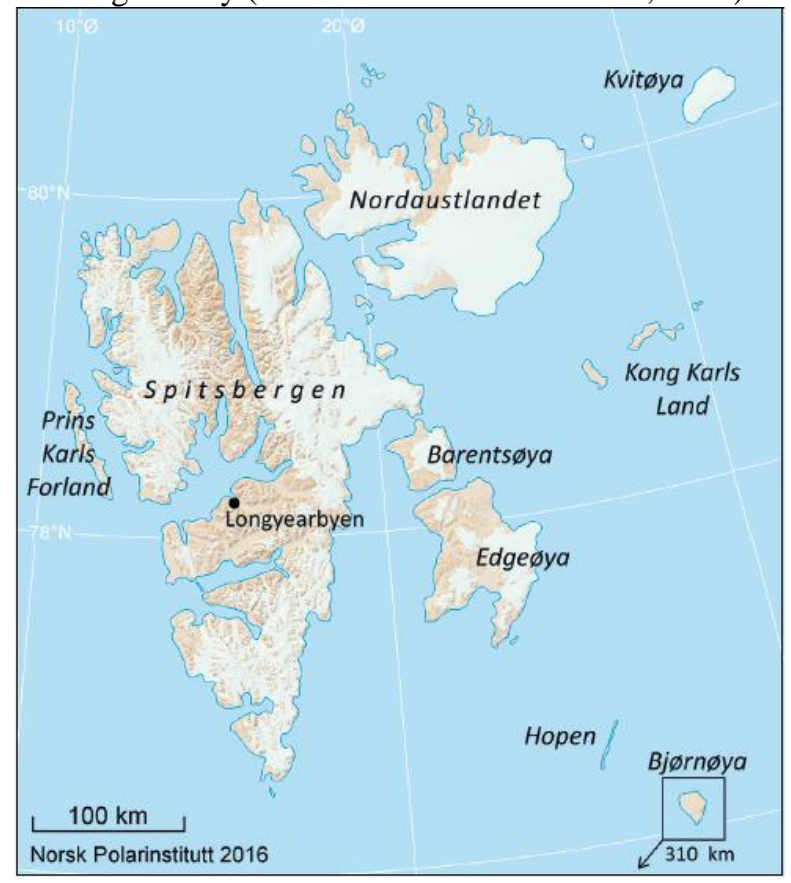

Figure 3. Svalbard Archipelago Map (NPI, 2021)

The islands were used as an expedition base for polar exploration as well as coal exploitation at the beginning of the twentieth century. And at present, a far-off Norwegian archipelago, just $1,000 \mathrm{~km}$ away from the North Pole, with an international status in the High North, Svalbard occupies a fundamental place for polar scientific researches as an exclusive part of the circumpolar natural laboratory. Thus, Svalbard has always been amongst the preferences of the Norwegian governments. Since the Arctic has become a part of the international economic and political systems (Southcott and Heinine, 2010) and the decrease in coal mining activities due to falling in the prices, the Norwegian government has boosted its efforts to establish a contemporary research community, particularly in $\mathrm{Ny}$ Ålesund. Today, there are twenty research stations of which fourteen are permanent from ten different countries in Ny-Ålesund (The RCN, 2019).

Longyearbyen which is the administrative center and hosts the governor's office has the largest infrastructure namely the Svalbard Science Center, University Center in Svalbard (UNIS), and some parts of the Norwegian Polar Institute (SSF, 2020). It has also become the main hub for international polar higher education. Consisting almost $20 \%$ of the population and producing nearly the same amount of economic activity, as the world's northernmost higher education center, UNIS has become the principal contributory institution to the community in Longyearbyen (Misund, Aksnes, Christiansen, and Arlov, 2017).

In addition to the mostly Norwegian population in Longyearbyen and international scientists and researchers in Ny-Ålesund, there is a Russian settlement in Barentsburg. Besides, in the south of the Spitsbergen Island at $77^{\circ}$ North latitude, Polish Polar StationHornsund was established in 1957 and modernized in 1978 (Misund et al., 2017; Polish Polar Station, 2020).

Having the fastest rate of global warming within the Arctic, multidisciplinary flagship programs have been developed and accomplished. With its international population, Svalbard is expected to experience more structural changes in the future.

\section{The Scope of the Spitsbergen (Svalbard) Treaty}

The situation of Spitsbergen, which did not belong to any country until the early twentieth century, changed when mining began to become an important industry in the region. As the land in the region started to become precious, the need for a reliable administration and legislation came to the fore. Many options were discussed, including joint management by Norway, Sweden, and Russia, which are the countries geographically close to Spitsbergen. As interest in the region waned due to the First World War, Norway persuaded other countries to take Spitsbergen under Norwegian rule during the post-war period of peace negotiations in Paris. Thus, with the "Spitsbergen Treaty" signed at Versailles on February 9, 1920, Spitsbergen officially came under Norwegian sovereignty. Today, this agreement is commonly referred to as the "Svalbard Treaty", although it is not historically correct (Spitsbergen-Svalbard.com, 2021). 
This treaty was enacted on 14 August 1925 with the term "Svalbard law" and entered into the Norwegian legal system. However, according to the treaty, Spitsbergen did not become a part of the country as it was on Norway's mainland (Royal Ministry of Justice, 1988; spitsbergen-svalbard.com, 2021). The treaty has some special stipulations that concern other countries. The important points highlighted in these stipulations are:

$>$ In Spitsbergen islands under Norwegian full and absolute sovereignty, citizens of all signatory states will have equal liberty of access and entry to the waters, fjords, and ports of the islands and may undertake economic activities "on a footing of absolute equality".

$>$ Nationals of signatory states may acquire, enjoy and exercise the right of ownership of property, the taxes, dues, and duties levied will be devoted only for Svalbard and will not exceed what is required.

$>$ No country, including Norway, is allowed to establish naval bases and to construct any fortifications in the islands, which may be used for military intentions (SpitsbergenSvalbard.com, 2021).

$>$ According to Article 10 of the Treaty, Third Powers will be invited by the Government of the French Republic to comply with the existing Treaty. The responsibility to notify other signatories will rest with the French Government (Royal Ministry of Justice, 1988; spitsbergen-svalbard.com, 2021).

\section{Economic importance of the Arctic region, natural resources, and emerging shipping routes}

The EU emphasized the importance of the maritime issues in 2007 and demonstrated the Integrated Maritime Policy (IMP). Five years later the EU decided to adopt the "Blue Growth Initiative" (Commission of the European Communities, 2007; European Commission, 2012). Blue Growth is a comprehensive approach that captures the entire marine and maritime sector. This long-term strategy's main purpose is to endorse feasible sea and ocean growth. The EU accepts the marine and maritime environment as stimulating variables for the European economy and has realized that there is a tremendous potential for sustainable economic growth in maritime contribution (European Commission, 2012). In this framework, the increasing importance of the Arctic Ocean is in the scope of the EU's agenda.

As the depositary state of the Svalbard Treaty and one of the important members of the European Union, France has repeatedly expressed its vital interest in Arcticrelated issues, such as scientific, economic, ecological ethics, political and defense subjects. France, a nonArctic state and an observer of the Arctic Council since 2000, highlights the importance of resources in the Arctic Ocean and also supports freedom of navigation. It is also concerned, directly or indirectly, with the far north part of the planet for worldwide scientific attraction. France wishes greater scientific collaboration in the area, where it seeks to actively participate by increasing its resources and investing more into Arctic science research. In June 2016, French Minister of Foreign Affairs and International Development, JeanMarc Ayrault pointed out France's financial interests in the Arctic region in a document (Ayrault, 2016).

Although there is uncertainty covering the exploitation of natural resources and secure utilization of opened-up Arctic maritime transportation routes as the results of constant and fast changes in the Arctic Ocean, new delimitation issues have surfaced. Even though the countries in the Arctic region will be affected greatly, considering the issues related to economic actions, environmental occurrences, and maritime security, it is required for France to surmount on to the region regarding national benefits and its international responsibilities and also considering its membership to EU and NATO which means that it has to contribute to retaining of the security and stability in the Arctic region (Ayrault, 2016). Although the military role of the Arctic has diminished since the cold war ended, there is still room for maneuver considering the conflict of interests, especially since Russia's strategic actions have changed. Russia's involvement in regional matters implies that the Arctic has slowly become a cooperation area among the Arctic 8 as well as NATO.

Seabed researches have not been carried out effectively for many years because of the large and intensive sea ice extent. But after the assessment report of the US Geological Survey completed in 2008, it is estimated that 90 billion barrels of oil, 1,669 trillion cubic feet of natural gas, and 44 billion barrels of natural gas liquids may be found in the region (Robertson, 2008).

With the increasing impact of global warming in the Arctic Ocean, new trans shipping routes have emerged that enable navigation between the North Atlantic Ocean and the North Pacific Ocean in a much shorter time. For example, while the current maritime trade route between Asia (Busan) and Northern Europe (Rotterdam) is approximately 11,450 nautical miles $(21,200 \mathrm{~km})$, these new routes could reduce this distance to approximately 7,240 nautical miles $(13,400 \mathrm{~km})$ (Figure 4). Attractive Trans-Arctic routes offer up to $\% 40$ shortcuts in the routes between the northern and central European and the north-eastern Asian ports, namely Chinese, Japan, and South Korean ports (Humpert, 2013; Mersin et al., 2019). Arctic maritime trade routes have the potential of reshaping the global transport geography in respect to liner and tramp shipping (Theocharis et al., 2018). Thus, maritime companies will not only save fuel but also will be able to get more voyage planning opportunities thanks to the ships completing their voyages in a shorter time. This great economic benefit that can be achieved has resulted in states as well as the companies feeling the need to operate in this region. But on the other hand, companies will be forced to have ice-class ships or to get icebreaker support during the voyages. This will reduce their profits (Aksenov et al., 2015; Zhang et al., 2016). 


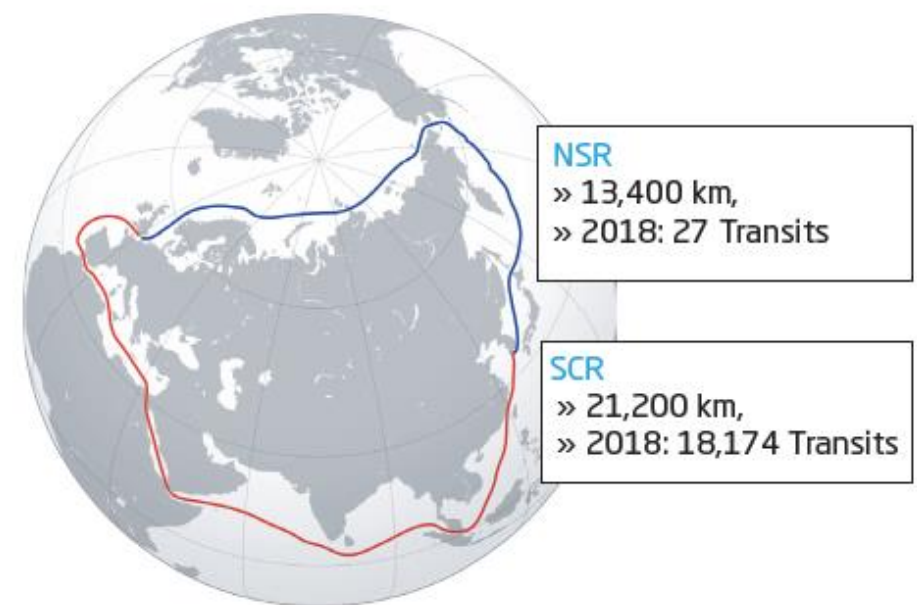

Figure 4. Suez Canal Route versus Northern Sea Route (German Arctic Office, 2020b).

Another important factor for the Arctic Ocean is that it has rich natural gas and oil deposits as well as minerals such as iron, copper, aluminium, nickel, phosphate, chromite, bauxite, and coal which have been discovered at very shallow depths. The discoveries of gold, diamond, and titanium, which are rare mines in the region show that the region will play an important role in the economy for the years to come. The fact that the region is home to a large number of sea creatures means that the fishing sector can also develop (Ragner, 2008; Lindstad et al., 2015; Zhang et al., 2016; Yumashev et al., 2017, Erol et al., 2021). The drilling of the natural resources and transportation of these extracted resources to the European and Asian markets will be possible by using Trans Arctic Sea Routes (Lindholt, 2006; Desjardins, 2016; Seval, 2019; Erol et al., 2021).

\section{Results and Discussion}

During the last year, the risks of working without stock due to the difficulties in supply chains started to direct companies to work with more stocks. It is thought that this change, which is seen as a shift from "just in time" production to "just in case" production, will give a new impetus to international shipping. It has become important to deliver products as quickly as possible in the global market. In this context, the Arctic Ocean routes may be discussed more, especially in the postpandemic period, as they provide shorter transportation times.

\section{Evaluation of the importance of the Arctic region}

Increasingly diminishing sea ice has attracted the regional countries to the delimitation of their maritime boundaries in the Arctic. The main reason for this strive is to gain control over some areas of the Arctic to be able to exploit economic advantages. Recently, the Arctic states have increased military expenses and operations to demonstrate their regional interests in the Arctic Ocean. Within this context, conventional maritime security risks, as well as the potential economic benefits of the region highly, attract the international community's attention to the Arctic. As of today, the maritime security issues highlighted in the Arctic region are national defense, sovereign rights, environmental changes, and natural resources extraction. With all the recent developments in the Arctic, and reviewing the new security concerns, it is needed to emphasize the emerging security strategies in the Arctic region with a view to its repercussions in global maritime economics. Countries that have a coastline to the Arctic Ocean namely Norway, Denmark, Canada, and the USA are also members of NATO. It may be foreseen that Russia, which had many contradictions with NATO in the past, will be confronted by NATO in the Arctic region in the future. In this context, it is evaluated that issues such as maritime jurisdiction, sharing of natural resources, and freedom of navigation may constitute contentious issues resulting in "conflict of interests" in the area which may cause a high possibility of the Arctic region becoming a "Possible Arctic Conflict Area" soon. A consistent and maintained Standing Naval Force-Arctic formed by NATO in the Arctic could assist in preserving stability and security in the region. Within this perspective as a NATO member Turkey may join to this naval force. However, the possibility of a confrontation between Russia and NATO would keep maritime security issues to continue to be on the priority list of the global agenda for the years to come.

In addition to the security perspective, it is possible to predict that the consequences of global warming in the Arctic Ocean will increase the importance of the islands of Svalbard, which has an effective geographic location. The Svalbard Islands perform a very important service for polar scientific research, as they have an international status as well as hosting the Global Seed Vault, which was created considering the possibility of humanity encountering a disaster.

On the northern part of the earth, among other places, the infrastructure of the Svalbard Archipelago provides an excellent opportunity for researchers and scientists to make research and observations as if it is a natural laboratory. The foundation of the Arctic Council as a high-level forum to develop cooperation and coordination among the Arctic states is very important for the governance of the Arctic, which is different from Antarctica. There are non Arctic states as the Arctic 
Council observers. These countries are China, France, Germany, India, Italy, Japan, Poland, Republic of Korea, Singapore, Spain, Switzerland, The Netherlands, and The United Kingdom. Additionally, 13 intergovernmental and inter-parliamentary organizations and 12 non-governmental organizations lay in this status. In the Arctic Council, all decisions are taken under the exclusive right and responsibilities of the eight permanent Arctic states. Only once observer status has been granted, countries having this role may be invited to the Arctic Council meetings. Observers, who have the right to observe the work of the Arctic Council, can contribute to the activities of the Council by participating at the level of Working Groups (The Arctic Council, 2021). Nevertheless, the determination of the non Arctic states to become the observer in the Council and efforts to gain legitimacy through established research stations and scientific expeditions are significant parameters for Turkey to consider before applying to Arctic Council.

\section{Turkey's interest in the Svalbard Treaty}

There has been an increase in scientific studies conducted in the Arctic region in the last 20 years. It is a known fact that besides the scientific benefits of the studies conducted in the region, it brings prestige to the countries that carry out these activities. In recent years, an environment of common understanding has been increasing among countries on the necessity of taking effective measures against global warming. From a political point of view to be among these countries will be a separate source of prestige for Turkey. It is also important to be "visible" in such activities to be among the active actors in global politics. After signing the Svalbard Treaty, like all the other nationals of the contracting parties, Turkish nationals will equally have been granted the right to engage in maritime, industrial, mining, or commercial activities on the Islands as well as in the territorial waters (Büyüksağnak and Özsoy, 2018). The Treaty also permits researchers and scientists to conduct scientific activities in the Islands and the students to attend higher education lectures in Arctic sciences at the Svalbard University Center. As a powerful country, Turkey's presence in all of the world's seas and oceans is among the activities that are required in terms of her national interests. From this point of view, it is important to evaluate the Northern shipping routes and mining opportunities that are likely to be used in the region.

Today, considered as the emerging global superpower, China was not invited to adhere to the Svalbard Treaty by France at the beginning. As the great state of the time, France later had to invite China to be a party to the Treaty to compete with the new rising power, the USA which was not satisfied with the results of the Paris Peace Conference and therefore initiated its own Washington Naval Conference in 1921 with the participation of the Republic of China (Liu, 2021). On the other hand, coincidentally, on just the same date with the signing ceremony ( $9^{\text {th }}$ of February, 1920) of the Svalbard Treaty, to recover their homeland during its Independence War, Turkish national forces were fighting against French military forces who occupied the south- eastern part of Anatolia (Kocatürk, 1983). In other words, the two states were at war when the agreement was signed. Naturally, France did not think to invite Turkey to sign the Svalbard Treaty then. The reason why Turkish diplomats remained uninterested in the Treaty since then remains a question mark.

After three national scientific expeditions to Antarctica (TAE-I, II, and III) between 2017-2019, Turkish scientists headed north in the summer of 2019 with the first Turkish Arctic Scientific Expedition (TASE) to show Turkey's interest in Arctic for the first time in the history. 7 researchers from different universities participated in the expedition between 11-26 July. In addition to gathering microplastic, plankton, seawater, and sediment samples from 14 various stations, air quality and maritime meteorology measurements, sea ice, and glacier observations were conducted in the cold waters around the Svalbard Islands. Selecting the Svalbard Islands as the site for the first Turkish Arctic Expedition was giving a hint to the international communities.

\section{Conclusion}

The growing importance of the Arctic Ocean and the maritime security interests of states extend to a practice that includes the projection of security beyond their territorial waters into international waters and perhaps global maritime areas. Considering that the common interests of humanity should be at the forefront rather than the interests of countries, it is important to establish the necessary understanding and policies regarding maritime security in the international arena without delay.

National polar scientific expeditions have contributed substantially to Turkey's global image. After four successful national expeditions, the next step of Turkey in Antarctic polar research activities should be to establish a sustainable scientific base on Horseshoe Island which lies in the Antarctic Peninsula. As Turkey historically has ambitions to take part actively in global politics, it has been participating in global challenges such as contributing to the fight against global warming and climate change by way of conducting national scientific expeditions and sending scientists to foreign scientific expeditions/stations at both Polar Regions.

It is also thought that it would be convenient for Turkey to be a party state to the Svalbard Treaty and join among the 46 signatory states, as of 2021. By signing the 101year treaty Turkey will, first of all, be able to show its interest and relevance in the Arctic region. Planning and executing the first national Arctic scientific expedition in 2019 particularly on and around the Svalbard Archipelago strongly supports that view as well. If Turkey becomes a party state to Svalbard Treaty, Turkish nationals will have the opportunity to get property ownership rights and equal liberty of access to the fjords and ports of the islands as well as conducting all commercial activities on an equal basis. 
Since Turkey, as a maritime country surrounded on three sides by seas, has significant potential with its merchant fleet and dynamic manpower within the maritime industry, it will have a great chance to take advantage of this potential considering the economic opportunities emerging for the global maritime transportation due to the recent developments in the Arctic Ocean. It is believed that after signing the Svalbard Treaty and maintaining the polar scientific expeditions, Turkey will finally become an observer member at the Arctic Council and have a chance to increase its prestige as a global actor.

\section{Acknowledgements}

We would also like to thank our editors and reviewers who contributed to the article with their constructive and supportive comments and suggestions.

\section{References}

ACIA. (2004). Impacts of a Warming Arctic: Arctic Climate Impact Assessment. Cambridge, UK: Cambridge University Press.

Aksenov, Y., Popova, E., Yool, A., Nurser, A., Williams, T., Bertino, L., Bergh, J. (2017). On The Future Navigability of Arctic Sea Routes: HighResolution Projections of The Arctic Ocean and Sea Ice. Marine Policy, 75, 300-317.

AMAP. (1998). AMAP Assessment Report: Arctic Pollution Issues, Arctic Monitoring, and Assessment Programme (AMAP), Oslo, Norway.

AMAP. (2017). Snow, Water, Ice, and Permafrost in the Arctic (SWIPA) 2017. Oslo, Norway. Arctic Monitoring and Assessment Programme (AMAP).

AMAP. (2019). AMAP Climate Change Update 2019: An Update to Key Findings of Snow, Water, Ice and Permafrost in the Arctic (SWIPA) 2017. Oslo, Norway. Arctic Monitoring and Assessment Programme (AMAP).

Ayrault, J. M. (2016). The Great Challenge of the Arctic National Roadmap for the Arctic, Paris: Press and Communication Directorate of the Ministry of Foreign Affairs and International Development of France.

Büyüksağnak, Y.B., Özsoy, B. (2018). Importance and Interest on Arctic and Svalbard Treaty, Polar 2018SCAR/IASC Open Science Conference, Davos, Switzerland.

Chater, A., Greaves, W. (2014). Security Governance in the Arctic. In Jim Sperling (Ed.), Handbook on Governance and Security, Edward Elgar Publishing, p.123-147.

Cheng, L., Abraham, J., Hausfather, Z., Trenberth, K. (2019). How fast are the oceans warming? Science, 363(6423), p.128-129.

Commission of the European Communities (2007). An Integrated Maritime Policy for the European Union.

Desjardins, J. (2016). The Energy and mineral riches of the Arctic.

Duggan, J. (2021). Inside the "doomsday" vault, TIME.

Erol, D., Çankaya, F.E., Çelik, B.B. (2021). Future of the commercial Arctic shipping and economic and environmental effects of starting to use of Northern sea route, Piri Reis University Graduate Thesis (un published).

Eurasian Geopolitics, Walker, E.D. (2021). Arctic Shipping Routes Map, University of California, Berkeley.

European Commission Directorate-General for Maritime Affairs and Fisheries (2012). Blue Growth: opportunities for marine and maritime sustainable growth: communication from the Commission to the European Parliament, the Council, the European Economic and Social Committee, and the Committee of the Regions. Publications Office of the European Union.

Fondahl, G., Sirina, A. (2006). Oil pipeline development and indigenous rights in eastern Siberia. Indigenous Affairs, (2-3), 58-67.

Gautier, D. L., Bird, K. J., Charpentier, R. R., Grantz, A., Houseknecht, D. W., Klett, T. R., et al. (2009). Assessment of undiscovered oil and gas in the Arctic. Science, 324(5931), 1175-1179.

German Arctic Office (2020a). Arctic and Antarcticmore differences than similarities? Fact Sheet, Alfred- Wegener Institut.

German Arctic Office (2020b). Shipping in the Arctic, Fact Sheet, Alfred- Wegener Institut.

Greaves, W. W. J. (2016). Constructing In/Security in the Arctic: Polar Politics, Indigenous Peoples, and Environmental Change in Canada and Norway (Doctoral dissertation).

Ho, J. (2010). The implications of Arctic Sea ice decline on shipping. Marine Policy, 34(3), 713-715.

Huebert, R., Exner-Pirot, H., Lajeunesse, A., and Gulledge, J. (2012). Climate Change and International Security: The Arctic as Bellwether. Center for Climate and Energy Solutions, Arlington, Virginia.

Humpert, M. (2013). The Future of Arctic Shipping: A new Silk Road for China?, The Arctic Institute, Center for Circumpolar Security Studies.

Kaltenborn, B.P., Østreng, W., Hovelsrud, G.K. (2019). The change will be the constant - future environmental policy and governance challenges in Svalbard. Polar Geography, Taylor and Francis Group.

Kocatürk, U. (1983). Atatürk ve Türkiye Cumhuriyeti Tarihi Kronolojisi 1918-1938, Türk Tarih Kurumu Basimevi, Ankara.

Lasserre, F. (2014). Case studies of shipping along Arctic routes. Analysis and profitability perspectives for the container sector. Transportation Research Part A: Policy and Practice, 66, 144-161.

Lindholt, L. (2006). Arctic Natural Resources in a Global Perspective. The Economy of the North. (eds.: S. Glomsrød and I. Aslaksen).

Lindstad, H., Bright, R., and Strømman, A. (2016). Economic savings linked to future Arctic shipping trade are at odds with climate change mitigation. Transport Policy, 45, 24-30.

Liu, N. (2021). China and one hundred years of the Svalbard Treaty: Past, present, and future, Marine Policy, 124104354. 
Mazo, J. (2014). Who Owns the North Pole? Survival, Global Politics and Strategy, Volume 56, 2014 Issue 1, p.61-70.

Mersin, K., Bayırhan, İ., Gazioğlu, C. (2019). Review of CO2 Emission and Reducing Methods in Maritime Transportation, Thermal Sciences, 23(6): 2073-2079.

Misund, O. A., Aksnes, D. W., Christiansen, H.H. and Arlov, T.B. (2017). A Norwegian Pillar in Svalbard: The Development of the University Centre in Svalbard. Cambridge University Press.

Moholdt, G., Hagen, JO, Eiken, T., Schuler, TV. (2010). Geometric changes and mass balance of the Austfonna ice cap, Svalbard, The Cryosphere, 4(1): 21-34.

National Snow and Ice Data Center (NSIDC) (2021a). All About Arctic Climatology and Meteorology, NSIDC.

National Snow and Ice Data Center (NSIDC) (2021b). All About Arctic Climatology and Meteorology, NSIDC.

Ostenso, N.A. (2021). Definition: Arctic Ocean.

Pezard, S., Tingstad, A., Hall, A. (2018). The Future of Arctic Cooperation in a Changing Strategic Environment: Insights from a Scenario-Based Exercise Organised by RAND and Hosted by NUPI, (May 8, 2018), Rand Corporation.

Polish Polar Station Hornsund (2020). Longyearbyen, Svalbard.

Ragner, C. L. (2008). Den norra sjövägen. In $T$. Hallberg (Ed.), Barents - ett gränsland i Norden (pp. 114-127). Stockholm: Arena Norden. English translation: The Northern Sea Route (1-8).

Riddell-Dixon, E. (2008). Canada and Arctic politics: the continental shelf extension. Ocean Development and International Law, 39(4), 343-359.

Robertson, J. (2008) 90 Billion Barrels of Oil and 1,670 Trillion Cubic Feet of Natural Gas Assessed in the Arctic, U.S. Geological Survey.

Royal Ministry of Justice (1988). The Spitsbergen Treaty, det kongelige justis-og politide partement Oslo.

Schuler, T.V.; Kohler, J.; Elagina, N.; Hagen, J.O.M.; Hodson, A.J.; Jania, J.A.; Kääb, A.M.; Luks, B.; Małecki, J.; Moholdt, G. (2020). Reconciling Svalbard Glacier Mass Balance. Front. Earth Sci. 8, $1-31$.

Selin, H., Mann, M.E. (2021). Global warming. Encyclopedia Britannica. Retrieved (31 January 2021).

Serreze, M. C., Barry, R. G. (2011). Processes and impacts of Arctic amplification: A research synthesis. Global and Planetary Change, 77 (1-2), 85-96, doi.10.1016/j.gloplacha.2011.03.004.

Seval, H. (2019). Arktik bölgede uluslararası siyasi düzen: teorik bir yaklaşım. Akdeniz İIBF Dergisi, 21. Yüzyıl Siyasetinde Kutuplar, 1-24.

Southcott, C., Heininen, L. Eds. (2010). Globalization and The Circumpolar North. Fairbanks: University of Alaska Press.

Spitsbergen-svalbard.com (2021). The Spitsbergen Treaty.

Svalbard Global Seed Vault (2021). 2020 Annual Brief.
Svalbard Science Forum (SSF) (2020). Research communities.

The Arctic Council (2021). Observers.

The Research Council of Norway (RCN) (2019). NyÅlesund Research Station Research Strategy.

Theocharis, D., Pettit, S., Rodrigues, V.S., Haider, J. (2018). Arctic Shipping: a systematic literature review of comparative studies, Journal of Transport Geography, 69, (112-128)

Togt, T.V.D. (2019). Conflict Prevention and Regional Cooperation in the Arctic. Clingendael - Netherlands Institute of International Relations.

Ülker, D., Ergüven, O., Gazioğlu, C. (2018). Socioeconomic impacts in a Changing Climate: Case Study Syria. International Journal of Environment and Geoinformatics, 5(1), 84-93, doi. 10.30897/ ijegeo.406273.

United Nations (2009). State of the World's Indigenous Peoples, ST/ESA/328, Department of Economic and Social Affairs, New York.

USGS (2008). Circum-Arctic Resource Appraisal: Estimates of Undiscovered Oil and gas North of Arctic Circle, Fact Sheet 2008-3049.

Yumashev, D., van Hussen, K., Gille, J., Whiteman, G. (2017). Towards A Balanced View of Arctic Shipping: Estimating Economic Impacts of Emissions From Increased Traffic on The Northern Sea Route. Climatic Change, 143: 143-155, doi.10.1007/s10584-017-1980-6.

Zhang, Y., Meng, Q., Zhang, L. (2016). Is the Northern Sea Route Attractive to Shipping Companies? Some Insights from Recent Ship Traffic Data. Marine Policy, 73, 53-60. 